\section{Foreign Body within Sphenoid Sinus: Multidetector-Row Computed Tomography (MDCT) Demonstration}

\section{Sfenoid Sinüs İcererisinde Yabancı Cisim: Cooklu Detektörü Olan Bilgisayarlı Tomografide Görüntüleme}

\begin{abstract}
Trans-nasal sphenoid sinus foreign body is a rare condition. We report a case of trans-nasal gun bullet within the sphenoid sinus with breach of the floor of the sella turcica. A 42-year-old soldier presented a few weeks after a gun battle with a history of headache. The skull x-ray demonstrated a foreign body in the region of sphenoid sinus and sella. Multidetector-row CT with multiplanar reformats demonstrated a bullet within the sphenoid sinus with its tip penetrating into the sella turcica. A few days later the patient coughed up the bullet as it came out spontaneously without any intervention. This is perhaps the unique occurrence of such a foreign body.
\end{abstract}

KEYWORDS: Foreign body, Functional endoscopic sinus surgery (FESS), MDCT, Sphenoid sinus

\section{ÖZ}

Nazal yoldan geçip sfenoid sinüs içerisine yabancı cisim geçmesi nadir görülen bir durumdur. Olgumuzda nazal yoldan geçen mermi sfenoid sinüs içinden geçip, sella tabanını kırıp ilerlemiş ve orada kalmıştır. 42 yaşında asker silahlı çatışmadan bir-kaç hafta sonra başağrısı yakınması ile tedavi altına alınmıştır. Düz röntgen grafisinde sfenoid sinüsün ve sella tursikanın mermi tarafından kısmen doldurulduğu izlendi. Bigisayarlı tomografide sfenoid sinüs içerisinde olan merminin uç kısmının sella tursikaya doğru uzandığı görüldü. Bilgisayarlı tomografi çekilmesinden birkaç gün sonra hastanın hapşırması sırasında mermi kendiliğinden dışarı atılmıştır. Yabancı bir cisme bağlı olarak görülen böyle bir oluşum muhtemelen literatürde sunulmuş ilk vaka olabilir.

ANAHTAR SÖZCÜKLER: Yabanc1 cisim, Fonksiyonel endoskopik sinüs cerrahisi, MDCT, Sfenoid sinüs

\section{Nisar Ahmad WANI ${ }^{1}$ \\ Abdul QAYUM KHAN² \\ 1 Sher-i-Kashmir Institute of Medical Sciences, Department of Radiology, Srinagar, J\&K, India \\ 2 Sher-i-Kashmir Institute of Medical Sciences, Department of Neurosurgery, Srinagar, J\&K, India}

Received : 10.09.2009

Accepted : 17.09.2009

Correspondence address:

Nisar Ahmad WANI

E-mail: nisar.wani@yahoo.com 


\section{INTRODUCTION}

Penetrating foreign body injuries of the face and paranasal sinuses are uncommon in civilian practice and war times. Orbit, maxillary and frontal sinuses are the structures most often involved. Sphenoid sinuses are deeply located and hence rarely damaged (2). The foreign body usually reaches the sphenoid sinus through the orbit or the nostril. However, close relationship to the vascular and neural structures predisposes to potentially life-threatening consequences in sphenoid sinus injuries (4). As multiplanar reformations can be generated with MDCT, it is the investigation of choice to identify the foreign body and to demonstrate the path of the missile and extent of the damage caused. CT also provides information for the planning of surgical procedure for the removal of a sphenoid sinus foreign body $(1,2,4)$.

\section{CASE REPORT}

A 42-year-old army man was involved in a gun battle with armed men three weeks before he presented in the emergency room with headache and posterior nasal discharge. At the time of the gun battle the patient had noticed slight nose bleed that settled after a few days with symptomatic treatment, and he apparently felt well afterwards for 10 days. He started experiencing the present complaints of headache and posterior nasal discharge one week previously. There was no visible facial injury or scar on local examination. He had no other complaints and CNS examination was normal. A skull x-ray was performed that showed a radio-opaque foreign body with the shape of a bullet in the region of the sella turcica and sphenoid sinus. A cranial CT scan was performed to localize the foreign body precisely (Figure 1,2). MDCT scan of the head with its coronal and sagittal reconstructions revealed that the bullet had traversed the nasal cavity and penetrated the floor of the right sphenoid sinus directly after entering the right nostril; the tip of the bullet had perforated the roof of the sphenoid sinus, that is the floor of the sella turcica. The main bulk of the bullet was lying within the sphenoid sinus with its tip within the sella turcica. The mucosa of the sphenoid sinus was thickened due to chronic sinusitis changes. Clinically, the patient did not have any features of pituitary insufficiency. Surgical removal of the pellet was planned and scheduled. The patient returned a few days later with the history of coughing up the bullet as it expelled spontaneously without any surgical intervention or complication. The route of expulsion was through the rent in the floor of the sphenoid sinus. Ours is the first reported case of spontaneous expulsion of sphenoid sinus foreign body without any endoscopic or surgical intervention.

\section{DISCUSSION}

A sinonasoorbital gunshot wound results in a severe soft tissue and bone lesion and is eventually a life-threatening condition. Depending on the course and trajectory, these missile track gunshot injuries can involve the paranasal sinuses, orbita,

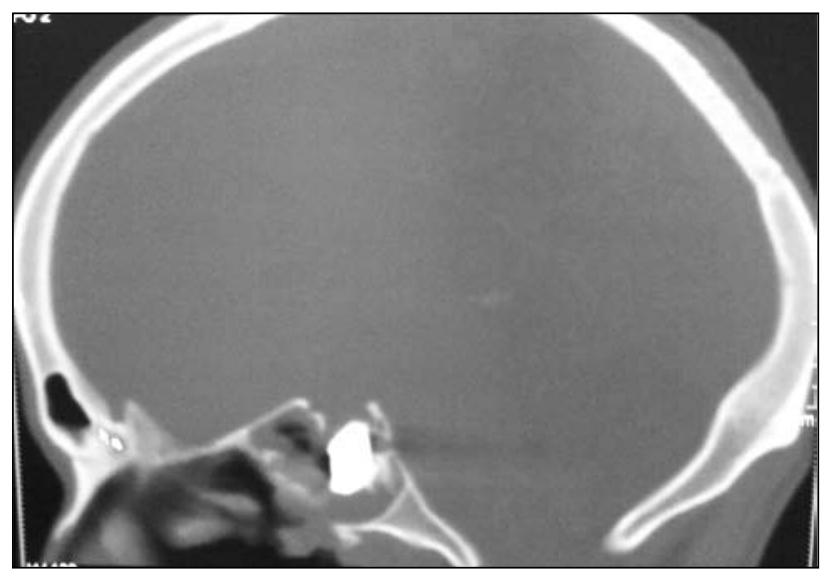

Figure 1: Sagittal plane reformatted image, showing bullet inside the sphenoid sinus with its tip perforating the floor of sella turcica; the mucosa of the sinus is thickened due to sinusitis.

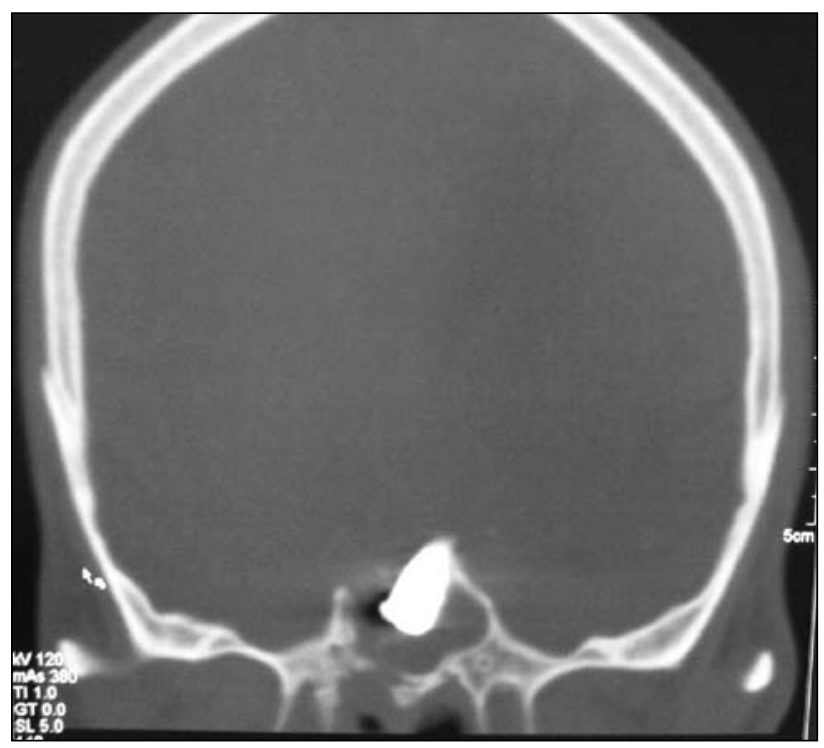

Figure 2: Coronal plane reformatted CT image showing bullet within sphenoid sinus and its tip penetrating into sella. There is breach of the inferior wall of sphenoid sinus on the right side of midline compatible with the entry site of the bullet. 
cranial nerves, or brain (1). Isolated sinus ballistic lesions are rare. An extremely high proportion of such injuries result from suicide attempts and accidents in adolescent males $(2,3,4,6)$. With the relatively low rate of these injuries, there are no standard methods of diagnosis and management. Patients with airgun wounds are taken to hospital, and immediate extensive preoperative examination with a combined ophthalmic, neurosurgical and otorhinolaryngological approach is recommended $(2,3)$. The main and most important diagnostic procedure available is computed tomography (CT) of the head providing accurate diagnostic information. It demonstrates the missile path, bone fragments, localization of retained airgun projectiles, and other lesions as well as the ways of possible removal. MDCT in several projections reveals an excellent intercourse of projectile and anatomical structures within the sinonasal region. The coronal CT scan provides a good view of the sphenoid and adjacent paranasal sinuses, and possible intracranial penetration $(1,2,3)$. In our case MDCT with multiplanar reformats revealed the location of the missile within the sphenoid sinus with breach of the floor and roof the sinus and no definite brain injury was seen. Magnetic resonance imaging (MRI) is usually a less informative diagnostic procedure for adequate imaging of bones. Angiography in the acute setting of such injuries is a rare diagnostic procedure, unless vascular laceration is suspected $(1,2)$. The overall Glasgow Coma Scale (GCS) score is used to evaluate the neurological status of the patient and is important for the outcome. After definitive diagnostic inspection, patients sustaining a brain injury with a GCS score of more than 7 require craniotomy. Surgical treatment of patients with a GCS score of 5 to 6 is individualized according to the bullet track, degree of brain injury, clinical situation, and expected outcome. Surgery is reserved for patients with a GCS score of 3 to 4 with dilated pupillae $(1,2)$. Patients who have paranasal sinus defect undergo surgery within 6 months using implants in selected cases $(3,4,7)$. In the past, the external approach was used. It became possible to accomplish the same task with minimally invasive surgery after endoscopic techniques (functional endoscopic sinus surgery - FESS) were brought to practice in the 1980s. Sinonasal endoscopy is safe, allows excellent visualization, and is the most appropriate method for removing the airgun projectiles in certain cases. Using stereotactic image guidance systems, FESS can be performed with even greater precision $(1,2,7)$. The decision to remove the foreign body should consider possible risks. Sphenoid sinus foreign bodies should be approached with special attention due to the close proximity of such important structures as the optic nerve and internal carotid artery. Skull base projectiles require special vigilance for possible cerebrospinal fluid leakage $(1,2)$. Though surgical removal of the intrasphenoid bullet was planned in our case, it came out spontaneously before the planned surgical procedure. We could not find any report of spontaneous expulsion of the sphenoid sinus foreign body in the literature. Reported long-term sequelae associated with retained bullets in paranasal sinuses include chronic sinusitis, cutaneous fistula, rhinolith formation, meningitis, chronic pain syndrome, or even malignancy. Long-time observation may increase the risk of poisoning because most retained metallic foreign bodies are made from lead. There have only been a few reports of paranasal foreign bodies observed without sequelae (5).

In conclusion, trans-nasal sphenoid sinus foreign body is a rare entity. MDCT is the investigation of choice with its coronal and sagittal reformations localizing the foreign body and demonstrating its path and extent of damage caused. Spontaneous expulsion of a sphenoid sinus foreign body is a really rare occurrence.

\section{REFERENCES}

1. Akhaddar A, Abouchadi A, Jidal M, Gazzaz M, Elmostarchid B, Naama O, Rzin A, Boucetta M: Metallic foreign body in the sphenoid sinus after ballistic injury: A case report. J Neuroradiol 35(2):125-8, 2008

2. Dimitriou C, Karavelis A, Triaridis K, Antoniadis C: Foreign body in the sphenoid sinus. J Craniomaxillofac Surg 20(5): 228-229,1992

3. Grevers G, Reiterer A: Traumatically-induced foreign bodies of the paranasal sinuses Laryngorhinootologie 69(3):155-157, 1990

4. Kitajiri S, Tabuchi K, Hiraumi H: Transnasal bamboo foreign body lodged in the sphenoid sinus. Tanaka T Auris Nasus Larynx 28(4):365-367,2001

5. Lubianca Neto JF, Mauri M, Machado JR, Ceccon A, Paimda Cunha C: Air gun dart injury in paranasal sinuses left alone. Int J Pediatr Otorhinolaryngol 52:173-176, 2000

6. Mori S, Fujieda S, Saito H: Numerous transorbital wooden foreign bodies in the sphenoid sinus. ORL J Otorhinolaryngol Relat Spec 61(3):165-168, 1999

7. Smirnov NM: Removal of a bullet from the sphenoid sinus of a child. Vestn Otorinolaringol 32(5):108-109, 1970 